\title{
BLAKE and FREUD
}

\author{
Diana Hume George
}

CORNELL UNIVERSITY PRESS

ITHACA AND LONDON 



\section{Copyright (C) 1980 by Cornell University}

All rights reserved. Except for brief quotations in a review, this book, or parts thereof, must not be reproduced in any form without permission in writing from the publisher. For information address Cornell University Press, 124 Roberts

Place, Ithaca, New York $14^{8} 5^{\text {o. }}$

First published 1980 by Cornell University Press.

Published in the United Kingdom by Cornell University Press Ltd., 2-4 Brook Street. London WIY IAA.

Excerpts from The Collected Papers of Sigmund Freud, edited by Ernest Jones, M.D., in five volumes. are reprinted by permission of Basic Books, Inc., which publishes them in the United States by arrangement with The Hogarth Press,

Ltd., and The Institute of Psycho-Analysis, London.

International Standard Book Number o-8014-1 286-2

Library of Congress Catalog Card Number 80-1 1244

Printed in the United States of America

Librarians: Library of Congress cataloging information appears on the last page of the book.
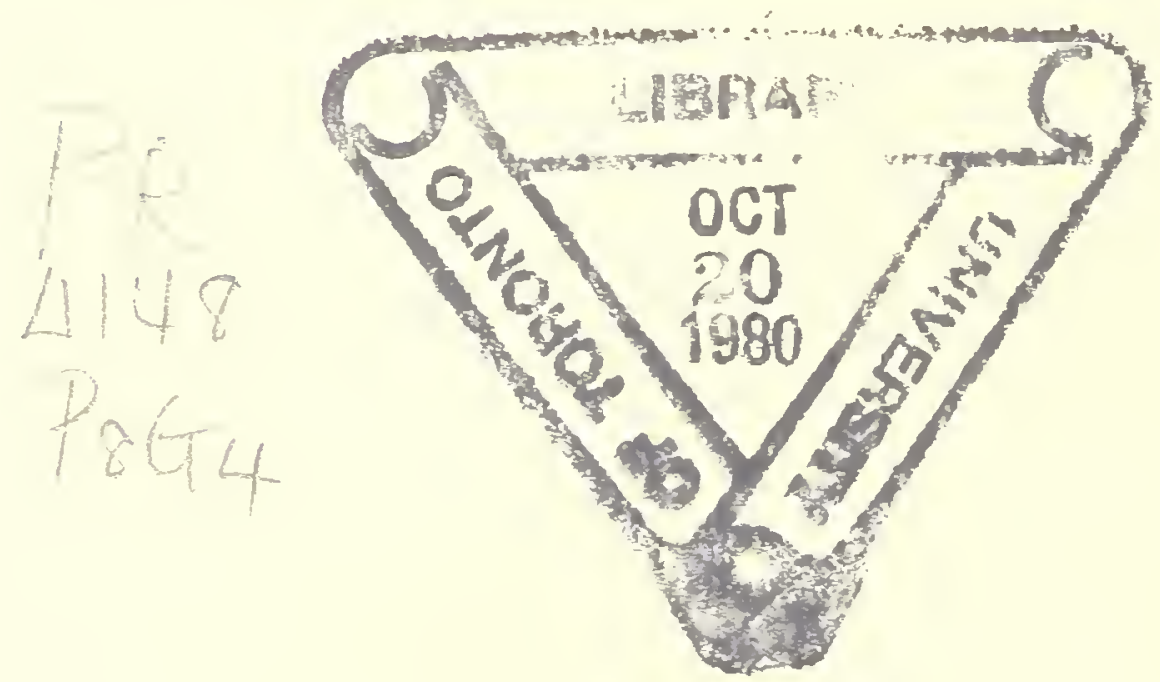
To Mac Nelson 
Digitized by the Internet Archive in 2018 with funding from

The Arcadia Fund 
